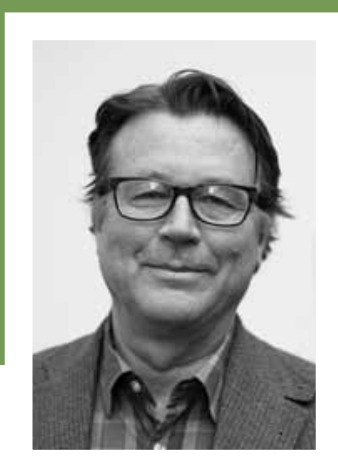

\title{
PÄ̈̈IRJOITUS
}

\section{SADAN VUODEN KOULUTUSPROJEKTI}

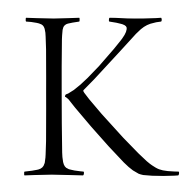

UN SUOMEN ITSENÄISYYDEN satavuotista historiaa kerrataan ahkerasti, saavutukset koulutuksessa eivät jää mainitsematta. Koulutus on nähty sekä itseisarvona että välineenä materiaalisen hyvinvoinnin kasvattamiseen. Itseisarvoa korostava ajattelu pohjaa käsitykseen koulutuksen ja sivistyksen ykseydestä.

Tärkeä osa sivistystä on tieteen tuottamaan tietoon perustuva käsitys maailmasta. Kansalaisella ei voi olla koskaan liikaa tietoa ja sivistystä. Se, minkä verran on tarpeeksi, on poliittinen päätös. Sekin on toki poliittinen kysymys, mitä tietoa ja millaisia tulkintoja maailmasta ja yhteiskunnasta koulutuksessa välitetään.

Monet tutkijat pitävät kansallisvaltion rakentamista ja populaatioiden hallintaa tärkeimpinä sysäyksinä kaikille kuuluvan kansanopetuksen aloittamiselle. Alkuaikoina kaikki vanhemmat eivät suinkaan pitäneet lastensa lähettämistä kansakouluun mielekkäänä. Koulutususko ja oppivelvollisuus piti ensin saada juurrutettua väestöön.

Koulutuksella on rakennettu "kansakuntia" ja saatu tietyllä alueella asuvat ihmiset tuntemaan keskinäistä kohtalonyhteyttä ja lojaalisuutta valtiolle. Koulutus on saanut samojen valtiollisten rajojen sisällä asuvat ihmiset näkemään itsensä meinä erotuksena heistä tai noista. Me olemme jotain erityislaatuista. Uskominen näihin kuviteltuihin yhteisöihin on saanut 2010-luvulla myös patologisia ilmenemismuotoja, kun "oikea" suomalaisuus oikeuttaa rasismin, syrjinnän, muukalaisvihan ja väkivallan käytön.

KUN ON MITATTU kansalaisten luottamusta yhteiskunnallisiin instituutioihin, tulokset ovat toistuvasti osoittaneet suomalaisten luottavan eniten poliisiin ja koulutusjärjestelmään. Taloudellisen tiedotustoimiston (TAT) viime vuonna tekemän kyselyn mukaan kumpaankin instituutioon ilmaisi luottavansa erittäin tai melko paljon yhdeksän kymmenestä kansalaisesta. Vertailun vuoksi todettakoon, että pääministeri Juha Sipilän (kesk.) hallitukseen luotti samana vuonna vain kolmannes kansalaisista.

Sipilän hallituskaudella onkin tapahtunut kaksi huomionarvoista muutosta: luottamus koulutukseen on jonkin verran vähentynyt ja luottamus alkanut eriytyä koulutusasteen mukaan. Vielä vuonna 2015 luottamus oli tasaisen korkealla tasolla niin keskiasteen kuin korkea-asteenkin suorittaneiden keskuudessa. Viimevuotisten tulosten mukaan se 
vähenee koulutusasteen laskiessa: eniten koulutukseen luottavat yliopistokoulutuksen saaneet ja vähiten enintään keskiasteen ammatillisen tutkinnon suorittaneet.

Luottamuksen hupenemisen taustalla vaikuttavat varmaankin hallituksen tekemät rahoituksen supistamiset. Erityisesti resurssileikkaukset yhdessä ammatillisen koulutuksen reformin kanssa ovat herättäneet huolta ammatillisen koulutuksen laadusta. Uudistuksen tavoitteena on lisätä oppimista työpaikalla ja mukauttaa ammatillista koulutusta elinkeinoelämän nopeasti muuttuviin tarpeisiin. Esimerkiksi Kansallinen koulutuksen arviointikeskus (Karvi) on lausunnossaan kiinnittänyt huomiota muutokseen sisältyviin vakaviin riskeihin.

YHTEISKUNNALLISESTI TÄRKEIMPIÄ riskejä on, että ammatillisen koulutuksen suorittaneiden tiedot heikkenevät ja sivistystaso laskee, mikäli tietopuolinen opetus saa väistyä työpaikan käytännön tarpeiden tieltä. Ammatillisen koulutuksen uudistajat eivät ole voineet välttyä kysymästä, minkä verran sivistystä on riittävästi: Onko kaikkien sivistystasosta huolehtiminen tarpeellista vai riittäisikö osalle vähempikin? Onko sivistyksestä taloudellista hyötyä? Sitäkin on kysytty, minkä verran säällisestä sivistystasosta kannattaa maksaa.

Pohdinnan arvoinen asia olisi sekin, mitä kansalaisten heikkenevästä tietotasosta joutuu tulevaisuudessa maksamaan. Toimiva demokratia ja valistuneet valinnat edellyttävät monimutkaistuvassa maailmassa yhä enemmän ymmärrystä ja kykyä kriittisesti seuloa pätevää tietoa informaatiotulvasta. Peruskoululaisten oppimistulokset eivät suinkaan ole paranemassa vaan heikkenemässä.

VIIME AIKOINA on tullut paljon uutta tietoa sukupuolten välisistä eroista oppimistuloksissa. Vuosien 2011 ja 2015 kansainvälisten TIMSS-arviointien mukaan tytöt ovat säilyttäneet hyvän osaamistasonsa matematiikassa, mutta poikien tulokset ovat huonontuneet kaikilla matematiikan alueilla. Pojat ovat tyttöjä selvästi heikompia niin matematiikassa, luonnontieteissä kuin lukutaidossa. Myös PISAarviointien mukaan osaamisen erot ovat kasvaneet. Heikkojen lukijoiden osuus on Suomessa kasvanut ja erinomaisten lukijoiden osuus supistunut. Suomessa sukupuolten välinen ero lukutaidossa tyttöjen hyväksi on PISA-maiden suurimpia.

Olennaista ei lopulta ole, että jonkin maan asema oppimistulosarvioinneissa suhteessa muihin maihin muuttuu. Sijoittuuko Suomi viidenneksi, kymmenenneksi vai viidenneksitoista, ei ole tärkeää. Monin verroin tärkeämpää on osaamistasossa tapahtuvan muutoksen suunta ja heikosti osaavien osuus ikäluokassa.

Sadan vuoden koulutusprojekti on silloin uudessa tilanteessa, kun lukutaito alkaa heiketä eikä yleissivistyksen ylläpitämiseen katsota riittävän rahaa.

Heikki Silvennoinen 